\title{
LEGAL CERTAINTY OF LEGALITY PRINCIPLE IN THE LEGISLATION OF THE CONTINENTAL AND ANGLO-AMERICAN SYSTEM
}

\author{
Andrey S. Burtsev ${ }^{1}$, Ehduard E. Genzyuk ${ }^{2}$, Elena F. Lukyanchikova ${ }^{3}$, Ivan V. Mironuk ${ }^{4}$, Marina L. \\ Prokhorova $^{5}$ \\ 1, 3, 4 Belgorod State University \\ 2 The Institute of service sector and entrepreneurship (branch) of DSTU in Shakhty \\ 5 Kuban state University \\ Address: 85 Pobedy Street, Belgorod, the Belgorod region, 308015, Russia
}

\begin{abstract}
In this article, through the comparative legal analysis of domestic, as well as foreign constitutional and criminal law norm content, various approaches to the principle of legality and its main features were examined. The authors have studied various ways of this principle criminal legal regulation and the problems that arise in this regard. It was concluded that the principle of legality has a different degree of certainty in the criminal legislation of different countries. This creates the conditions conducive to the making of unlawful judicial decisions that undermine the authority of national courts and compel people to apply for protection to supranational courts.
\end{abstract}

Keywords: legality, continental, Anglo-American System

\section{INTRODUCTION}

In recent years, the criminal law of almost all democratic countries have undergone conceptual changes aimed at the protection of rights and freedoms of every human being and human values. They become the primate of criminal law and not the protection of a state and the "sacred right of ownership". Legality (together with the presumption of innocence), which acts as one of the key guarantees of individual rights, is the indicator of the level of justice and humanity achieved by a state [8]. Having passed a long and a complex path of development, the principle of legality has been the object of scientific research by legal scholars of various countries many times. However, a unified approach to its content has not developed both in theory and in legislation [11]. We believe that the variability of scientific views on the criminal legal fixation of legality principle in the legislation of different countries requires a systematic analysis of this legislation in order to unify the features of the declared principle.

\section{METHODOLOGY}

The work used the provisions of dialectics, general scientific, special and private methods. In the course of the study, the following private-scientific methods were also used: historical-legal, formal-legal, formal-logical, systemic and comparative one.

\section{DISCUSSION AND RESULTS}

The demand of legality to bring to criminal responsibility was registered initially in the form of a classical Roman formula: "nullum crimen, nulla poena sine lege". In Europe, the principle of legality appeared first in the text of the French Declaration of Human Rights and Citizen of 1789, which determined that only the law should impose penalties [18]. In the North American continent, the principle of legality was proclaimed by the Constitution of Maryland in 1776 [9].

Today, the importance of legality principle is demonstrated by its consolidation on the international legal level in the acts of a universal nature (for example, the Article 66 of the Rome Statute of the International Criminal Court (1998)) [15] and in national constitutions and criminal codes. Specialized human rights instruments also pay attention to this fundamental principle. Thus, the World Congress of the 
International Association of Criminal Law, held in September 1979 in Hamburg (Germany), confirmed the need to convict a person only on the basis of a court decision and in accordance with the procedure established by law [10, pp. 10-11].

It can be argued that in modern times the principle of legality is reduced to the axiom on the punishability of a wrongful act solely in accordance with the law. Based on this interpretation, each state interprets it according to the specifics of its legal system, which leads to the differences in the understanding and a legislative expression of this principle in national criminal law. This leads to the reduction of its potential in the sphere of criminal justice, impedes the implementation of human rights and freedoms protection guarantees from an unlawful conviction.

First of all, these differences are related with the recognition of international law as an independent source of an act criminalization (along with the domestic law).

In most countries of the world, legal systems do not presuppose the possibility of an act criminality determination by international law. The legislation of individual countries makes an exception. For example, the Constitution of Portugal recognizes the possibility of punishment for an act recognized at the time of its commission as criminal one by generally recognized norms of international law (Article 29) [9], and the Constitution of France establishes the primacy of ratified international treaties over domestic laws (Article 55) [9].

It should be noted that the Russian criminal law doctrine, referred to the continental legal system, has always held the view that the criminal wrongfulness of an act can be determined only by national law. This postulate is recorded officially (Part 1, Article 3 of RF Criminal Code) [19].

One of the most important signs of legality principle in the states of the Romano-Germanic (continental) legal family is the prohibition on the application of criminal law rule by analogy. In Germany, Italy, France, the inadmissibility of such an analogy is grounded in the doctrine and is recorded by the law. However, the criminal codes of Denmark and Iceland admit the analogy of the criminal law directly and are not receptive to the legal experience of their neighbors.

In Russian Federation the judicial and investigative practice does not exclude such an application, even if there is an imperative prescription of the criminal law (Part 2, Article 3) [19], which does not allow its use by analogy. For example, if it is necessary to overcome the gaps in criminal law regulation. However, this is more an exception than the rule.

Arguing about the law as a source of act criminalization, the countries of the continental system of law are characterized by a strict understanding of legality principle: crime and punishment can be provided only by law. In Germany, the principle "there is no punishment without the law" is recorded in par. 3 of the article 103 of the Constitution [9] and in $\S 1$ of the Penal Code: an act is punished only if the punishability is determined by the law adopted prior to its commission [2].

In France, the current Constitution is also considered as the source of criminal law [9]. It contains the reference to the Declaration of Human and Citizen Rights issued on August 26, 1789, which determines that a charge, an arrest or an imprisonment can be carried out in the cases determined by law (Article 7). A similar formulation is also contained in the Article 111-3 of the Criminal Code of France [3].

Besides, the system of criminal law in France includes the laws containing criminal law (About the Press, 1881) [12], (About Commercial Societies, 1966) [13, pp. 64-65], etc. In Germany, the so-called additional criminal law (Nebenstrafrecht), covers about 1,000 laws.

Historically, the system of common law was formed in England. However, gradually an act crime began to be provided also by law (a statute), while preserving the significance of the precedent. Currently, criminal law is contained in various legislative acts of non-criminal nature and in special laws on specific institutions of criminal law [6], for example, in the Criminal Law Acts of 1967 [4] and 1977 [5], etc.

Submit Date: 12.01.2018, Acceptance Date: 26.02.2018, DOI NO: 10.7456/1080MSE/128

Research Article - This article was checked by Turnitin

Copyright (C) The Turkish Online Journal of Design, Art and Communication 
In addition to numerous laws, the scientific doctrine is the source of the criminal law of England. First of all, this is the famous work by W. Blackstone "The comments to the laws of England" in 1765 [1]. Nowadays, the most famous works influencing the development of English criminal law are the works by Kenya, Cross, Jones and Glanville Williams [11].

In the United States the classic expression of legality principle was recognized first of all by American lawyers [7, p. 39] and then it was reflected in the United States Penal Code draft: the conduct does not constitute an infringement without its recognition as a crime or a violation under this Code or a state statute [14]. The Code influenced the adoption of the judiciary (for example, in the state of New York), and more often legislative (for example, in the state of Ohio or Kentucky) prohibitions on punishment in some states under the rules of common law. However, in some states (for example, Florida, Idaho), common law crimes are recognized fully, and in some states (Maryland, Oregon) only partially [16, p. $15]$.

An important feature of legality principle is the requirement of criminal law certainty. It is contained in the legislation of individual countries of the continental legal system and the United States. In Russia, the criterion of the legal norm certainty as a constitutional requirement was formulated in the decisions of RF Constitutional Court. Thus, Resolution No. 8-P issued on May 27, 2008 noted that the prohibitions and other regulations fixed in the law should be specific, clear and unambiguous [17].

In the US criminal law, the feature in question was reflected in the doctrine of "insignificant because of ambiguity". In accordance with it, the Supreme Court of the United States or the State which determined that a statute is formulated vaguely and not clearly, can consider this statute null and void. Thus, the constitutional and criminal legislation of most countries in Europe and the United States has different approaches to secure the substantive aspect of the rule of law.

First of all, the study revealed the divergence in the recognition of the national law exclusivity as a source of an act criminalization. If in France, Portugal and a number of other European countries the possibility of criminal recognition in accordance with universally recognized norms of international law is recorded at the constitutional level, the Constitution of Russian Federation does not contain this provision, allowing the application of international treaty rules in certain cases (Part 4 of the art. 15). Such a legal position seems to us more flexible, which allows us to take into account the variability of international law without giving up the primacy of national criminal legislation.

The next peculiarity, concerning the content of legality principle, is connected with the existence of laws containing criminal prescriptions in Austrian, Swiss, French and German criminal legislation (other than criminal codes). We believe that this leads to casuistic legislation inevitably, violates its legal harmony, makes it difficult to protect against unlawful conviction.

However, the greatest deviation from the classical formula of legality principle is recorded in England and in the United States, where the significance of a precedent is preserved to a large extent. The latter is vulnerable to the violations of individual rights of those held accountable due to the weakness of the criminal legislation, an unlimited judicial discretion, and for other reasons. We can say that the principle of legality in the generally accepted meaning, that is, as it is understood in the countries of the continental system of law, in the US and in England acts with significant reservations, or does not operate at all.

That is why the new laws in Russian Federation providing for criminal liability are subject to the inclusion in the criminal code (Part 1, Article 1). This approach of the legislator seems to us the most optimal one, increases the potential and is a positive feature of national legislation.

In the issue of criminal law certainty, the criminal legislation of almost all democratic countries does not have any specifics. At the same time, the doctrinal interpretation of this feature implies the presentation of the law by the language clear and sufficient for understanding. 


\section{CONCLUSIONS}

A comparative legal analysis of the constitutional and criminal law norms, which establish the principle of legality in different countries, led to the conclusion that the declared principle with different degrees of legal certainty found its normative fixing in national legal systems. At the same time, they revealed the conceptual differences in the understanding of the criminal legal significance of the principle and its features.

We believe that a single, model approach to the characteristics determining the legal nature of the principle of legality should be worked out at the international level. These include:

1) the prohibition of criminal law application by analogy;

2) the requirement of criminal law sufficient certainty;

3 ) the exclusivity of law as a source of an act criminalization;

4) the recognition of international law as a source of an act criminalization.

We believe that the implementation of legality principle in the proposed interpretation will be an effective protection of human rights from possible violations.

\section{REFERENCES}

Blackstone W. Commentaries on the laws of England. Beason Press, 1962.

Criminal Code of the Federal Republic of Germany (1971, amended 2013) //

http://www.legislationline.org/documents/section/criminal-codes (accessed 17 February 2018).

Criminal Code of the French Republic (as of 2005) //

http://www.legislationline.org/documents/section/criminal-codes (accessed 17 February 2018).

Criminal Law Act. 1967.

Criminal Law Act. 1977.

Criminal Law. Codification of the Criminal Law. A Report to the Law Commission (Law Com. № 143).

_ L., HMSO, 1985.

Dressler J. Understanding criminal law. Matthew Bender \& Company, 2001. pp. 639.

Ivan V. Mironuk, Andrey S. Burtsev, Anzhelika I. Lyakhova, Elena F. Lukyanchikova, Andrey V.

Stepanyuk Formalization of Innocence Presumption Principle in the States of the Post-Soviet Space //

INTERNATIONAL JOURNAL OF SCIENTIFIC STUDY. Volume 5, Issue 8. P. 327-330.

http://worldconstitutions.ru/ (accessed 1 March 2018).

Kasumov C. The presumption of innocence in Soviet law. Baku Elm, 1984. Pp/ 138. (In Russian).

Kenny C.S. Outlines of Criminal Law, 1965; Cross R. and Jones P.A. Introduction to Criminal Law, 1988; Williams G. Criminal Law. The General Part, 1961.

Law of 29 July 1881 on freedom of the press //

https://www.legifrance.gouv.fr/affichTexte.do? cidTexte $=$ LEGITEXT000006070722 (accessed 17

February 2018).

Meleshko N.P., Tarlo E.G. Criminally-legal systems of Russia and foreign countries (criminological problems of comparative law, theory, legislative and law enforcement practice). M., 2003.pp 304. (In Russian)

Model penal code: The American Law Institute Proposed Official Draft / Trans. with English. A.S.

Nikiforova; Ed. B.S. Nikiforova. - M., 1969. - pp. 303.

Rome Statute of the International Criminal Court 1998 // http://legal.un.org/icc/statute/romefra.htm

(accessed 17 February 2018).

Samaha J. Criminal law. St. Paul (MN), 1993.

SZ RF. 2008. № 24. Art. 2892.

The Canadian Charter of Rights and Freedoms // http://laws-lois.justice.gc.ca/eng/Const/page-15.html (accessed 17 February 2018).

The Criminal Code of the Russian Federation of June 13, 1996, No. 63-FZ (as amended on 06/07/2016)

// Meeting of the legislation of the Russian Federation. - 1996. - No. 25, art. 2954.

Research Article - This article was checked by Turnitin

Copyright (C) The Turkish Online Journal of Design, Art and Communication 